\title{
A reassessment of 'Globigerina bathoniana' Pazdrowa, 1969 and the palaeoceanographic significance of Jurassic planktic foraminifera from southern Poland
}

\author{
MALCOLM B. HART ${ }^{1 *}$, WENDY HUDSON ${ }^{1}$, CHRISTOPHER W. SMART ${ }^{1}$ \& JAROSŁAW TYSZKA ${ }^{2}$ \\ ${ }^{1}$ School of Geography, Earth \& Environmental Sciences, Plymouth University, Drake Circus, Plymouth PL4 8AA, UK \\ ${ }^{2}$ Institute of Geological Sciences, Polish Academy of Sciences, Research Centre in Kraków, ul. Senacka 1, Kraków 31-002, Poland \\ *Corresponding author (e-mail: mhart@plymouth.ac.uk)
}

\begin{abstract}
Globigerina Ooze', Foraminiferal Ooze or Carbonate Ooze as it is now known, is a widespread and highly characteristic sediment of the modern ocean system. Comparable sediments are much less common in the geological record although, as we describe here, a number of Middle Jurassic carbonate sediments with distinctive assemblages from Central Europe fulfil many of the criteria. One important component of these assemblages in the Middle Jurassic is 'Globigerina bathoniana' Pazdrowa, 1969, first described from the Bathonian sediments near Ogrodzieniec (Poland). The generic assignment of this species and other coeval Jurassic taxa is discussed. This species and many of the other early planktic foraminifera evolved in the Aragonite 11 Ocean, together with the other two oceanic carbonate producers: the calcareous nannofossils and the calcareous dinoflagellates. The preservation of carbonate sediments with abundant planktic foraminifera on the sea floor indicates that, by the mid-Jurassic, the carbonate/aragonite compensation depths (and associated lysoclines) must have developed in the water column. J. Micropalaeontol. 31(2): 97-109, July 2012.
\end{abstract}

KEYWORDS: Jurassic, planktic foraminifera, palaeoceanography, Aragonite ll Ocean

\section{INTRODUCTION}

'Globigerina Ooze' (= Foraminiferal Ooze) or Carbonate Ooze as it is more commonly known is a widespread and highly characteristic sediment of the modern ocean system. It is represented by a carbonate-rich (>95\%) sediment with little, if any, detrital component. The planktic foraminiferal assemblage, which defines the environment, is dominant $(>95 \%$, but often $>99 \%)$ and benthic taxa are extremely rare (often $\sim 1 \%$ ). Such sediments are quite rare in the geological record, becoming less common further back in time. In the Middle Jurassic of Europe (Poland, Hungary, Italy, etc.) are some of the oldest known examples of Carbonate Ooze, with rocks composed of $>95 \%$ planktic foraminifera. The planktic foraminifera are thought to have evolved in the Toarcian (Wernli, 1988, 1995) and these Middle Jurassic occurrences indicate that the planktic foraminifera must have evolved and dispersed quickly in the Jurassic oceans (Hudson et al., 2009).

In 1967 Fuchs described assemblages of early planktic foraminifera from the Middle and Upper Triassic of Austria and northern Italy. These taxa were thought to be closely related to the Oberhauserellidae and other aragonitic genera and species known from the earlier work of Oberhauser (1960). Subsequent studies of his material, which is housed in the collections of the Geological Survey of Austria in Vienna, have concluded that the majority, if not all, of his proposed planktic foraminifera are probably benthic. In a later paper, Fuchs (1973) described an assemblage of planktic foraminifera from the Callovian and Oxfordian sediments of southern Poland. Most of the new taxa he proposed were immediately invalid as the material was almost exclusively in the form of glauconitic infillings (Glaukonitkern). One of the new genera was Polskanella, created in an attempt to clarify the status of Globigerina oxfordiana Grigelis, 1958. These revisions failed and there is still a need to resolve the taxonomic position of these midJurassic planktic foraminifera. An important component of the problem is the status of Globigerina bathoniana Pazdrowa, 1969, one of the earliest, well-described species of planktic foraminifera.

\section{'GLOBIGERINA BATHONIANA' PAZDROWA, 1969}

'Globigerina bathoniana' was initially described from the Middle Bathonian strata of Ogrodzieniec (Poland) in 1969. In her account, Pazdrowa (1969, p. 45) indicates that she had at her disposal 150 well-preserved specimens of the new species from the ore-bearing clays of the Morrisi Chronozone (Fig. 1). As the mid-Jurassic ammonite succession is well known in the Ogrodzieniec/Częstochowa area (see Wierzbowski et al., 2006 and references therein) this age determination is regarded as very accurate. All her material, including separate slides for her figured specimens, is in the Geological Museum of the Institute of Geological Sciences, Polish Academy of Sciences in Kraków. Many of her slides are dated 1958, although the publication they relate to was published in 1969.

In September 2009, Barbara Kietlińska-Michalik, Head of the Geological Museum in Kraków, provided access to the complete collection of Pazdrowa's material together with microscope facilities for their study. The material is all clearly labelled and it was possible to see each of the specimens figured in her paper, including the holotype.

The holotype of ' $G$. bathoniana' is very well described in virtually every detail (see Pazdrowa, 1969) and has been photographed in Plate 1 (fig. 1a-d). The high spire is distinctive, and very pointed, with a small initial chamber. The number of chambers and the characteristic four inflated chambers in the final whorl are both distinctive features (Pl. 1, fig. 1a, b). The umbilical aperture is a large, semi-circular 'arch' bordered (on the peripheral side) by a lip that is possibly a little less prominent than that shown in the illustration of the holotype (Pazdrowa, 1969, fig. 1c; see P1. 1, fig. 1b, c). Marks on the chambers adjacent to the umbilical aperture suggest that the holotype may have carried a bulla-like structure that has been completely lost (P1. 1, fig. 1d). Pazdrowa undertook some statistical analysis of the proloculus size in order to compare her specimens with Globigerina dagestanica Morozowa (in Morozowa \& Moskalenko, 1961). She also compared her new species to other taxa and carefully 


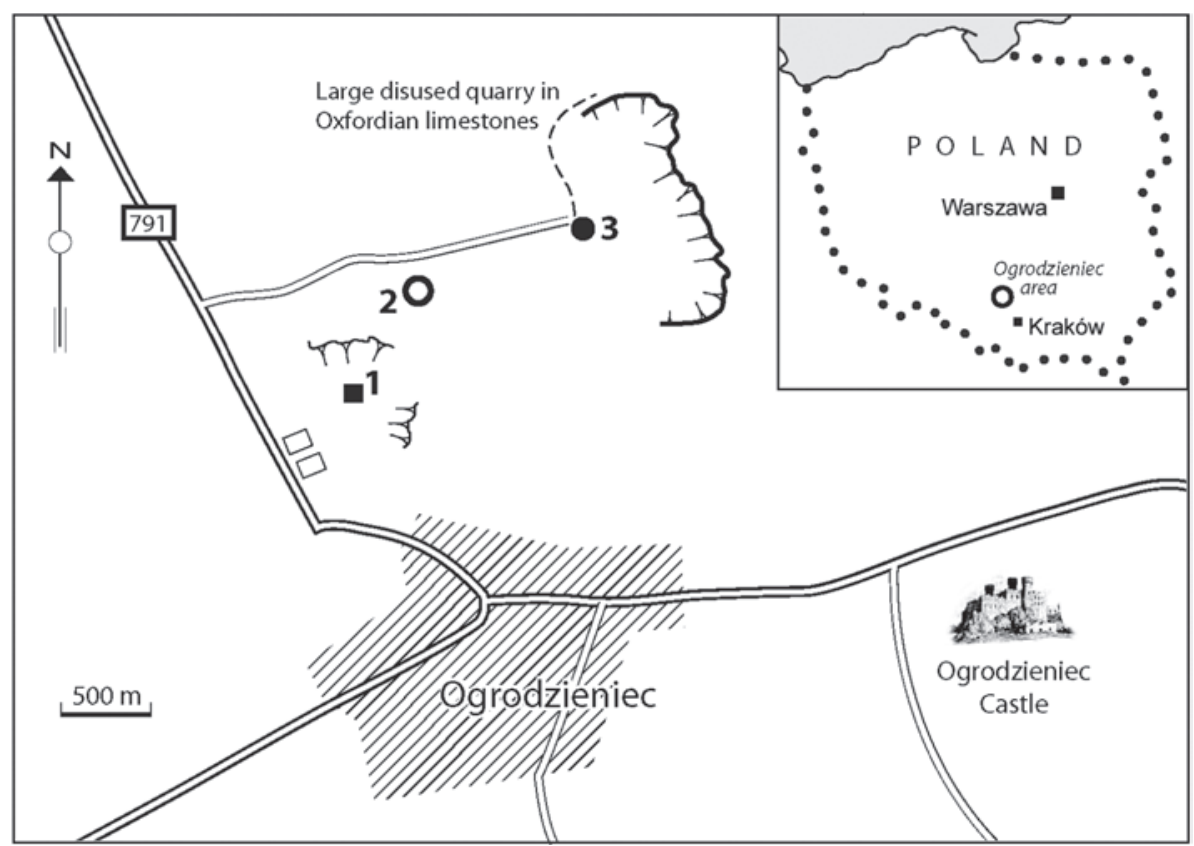

Fig. 1. Map of the Ogrodzieniec area showing the location of the village, castle, large quarry in the Oxfordian limestones $\left(50.464646^{\circ} \mathrm{N}, 19.518619^{\circ} \mathrm{E}\right)$, sampled outcrops of the Ogrodzieniec Glauconitic Marl Formation $(2,3)$ and the abandoned quarries (1) in the Bathonian clays from which Pazdrowa (1969) collected the material used in the original definition of Globigerina bathoniana and which have been re-sampled in June 2011. These former clay pits are now badly degraded and, without intervention, it will soon be impossible to collect a measured section through this part of the Bathonian succession at this locality. It should be noted that locality (2) was the temporary exposure of the Callovian/Oxfordian boundary succession prepared for the International Symposium on the Jurassic System (ISJS) in September 2006 (Wierzbowski et al., 2006, pp. 144-148, fig. B1.8). Locality (3) was found in June 2011 and is a very small roadside exposure of the Ogrodzieniec Glauconitic Marl Formation that contains abundant belemnites and ammonites.

itemized the differences (Pazdrowa, 1969, pp. 51-52). It is particularly important to note that she separated $G$. bathoniana from Globigerina oxfordiana Grigelis (1958) on the basis of spire height, commenting that the two species were "very similar in the shape and position of the aperture and lip, and arrangement of chambers'. At that time, of course, Pazdrowa did not have the later publications of Grigelis (1985), Grigelis \& Gorbachik (1980) or the emendations of Bignot \& Guyader (1971) and Bignot \& Janin (1984) as a guide to her interpretation of the new species.

In the slides (DG-2, DG-5, DG-6, etc.) are a range of specimens that match the illustrations (Pazdrowa, 1969, figs 1-9) very well. While the majority of forms are pointed and high-spired, some (DG-3, DG-15) have a lower spire (Pl. 1, fig. 3a-d). The high-spired specimen (DG-11) has a very distinctive loop-shaped aperture (Pazdrowa, 1969, fig. 7) extending almost halfway up the face of the final chamber (Pl. 1, fig. 4c, d). DG-17 also shows a loop-shaped aperture although, in this case, it appears rather tilted to one side in the final chamber.

Other slides (un-numbered) contain a range of high-spired and low-spired forms. One radially segmented slide contains an assemblage with a full range of spire height, all of the specimens having 'arch'-shaped apertures. Only one or two specimens have distinct apertural lips. In summary, therefore, Globigerina bathoniana, as originally defined, is a species characterized by:

- approximately 12 chambers arranged in 2.5 to 3 whorls of (almost invariably) 4 chambers;

- an 'arch'-shaped aperture with a developed to less-developed apertural lip;
- some evidence of the presence of a bulla-like structure (usually broken off completely); and

- a high to very high spire, which - in many specimens - is very pointed (with a small proloculus).

In the assemblage there are forms that have a low trochospire and some (quite rare) specimens that possess a loop-shaped aperture (Pl. 1, fig. 4c, d). All these morphological variations were illustrated by Pazdrowa and this has been confirmed by this investigation. Forms typical of Pazdrowa's assemblage are illustrated in Plates 1 and 2.

Following the re-classification of Simmons et al. (1997) the majority of Pazdrowa's specimens would clearly fall within the definition of Conoglobigerina while a few of the specimens in her collection could fall into Globuligerina (with a loop-shaped aperture). Conoglobigerina (sensu Simmons et al., 1997, p. 20) is defined as a genus of the Family Conoglobigerinidae 'with an intraumbilical aperture, which is an interiomarginal low arch'. This family is defined by Simmons et al. (1997, p. 20) as being separated from other members of the Superfamily Favusellacea by the lack of a 'favose surface structure of fused pseudomuricae forming an anastomosing reticulation': a feature that characterizes the genus Favusella. Globuligerina, however, is defined as 'Conoglobigerinidae with an intraumbilical aperture which is loop-shaped with a distinct lip'. This follows the definition, emendations and illustrations of Bignot \& Guyader (1971).

Simmons et al. (1997) clearly illustrate some forms of Globuligerina bathoniana with a loop-shaped aperture, including a metatype (Simmons et al., 1997, pl. 2.8, fig. 9) and a topotype 


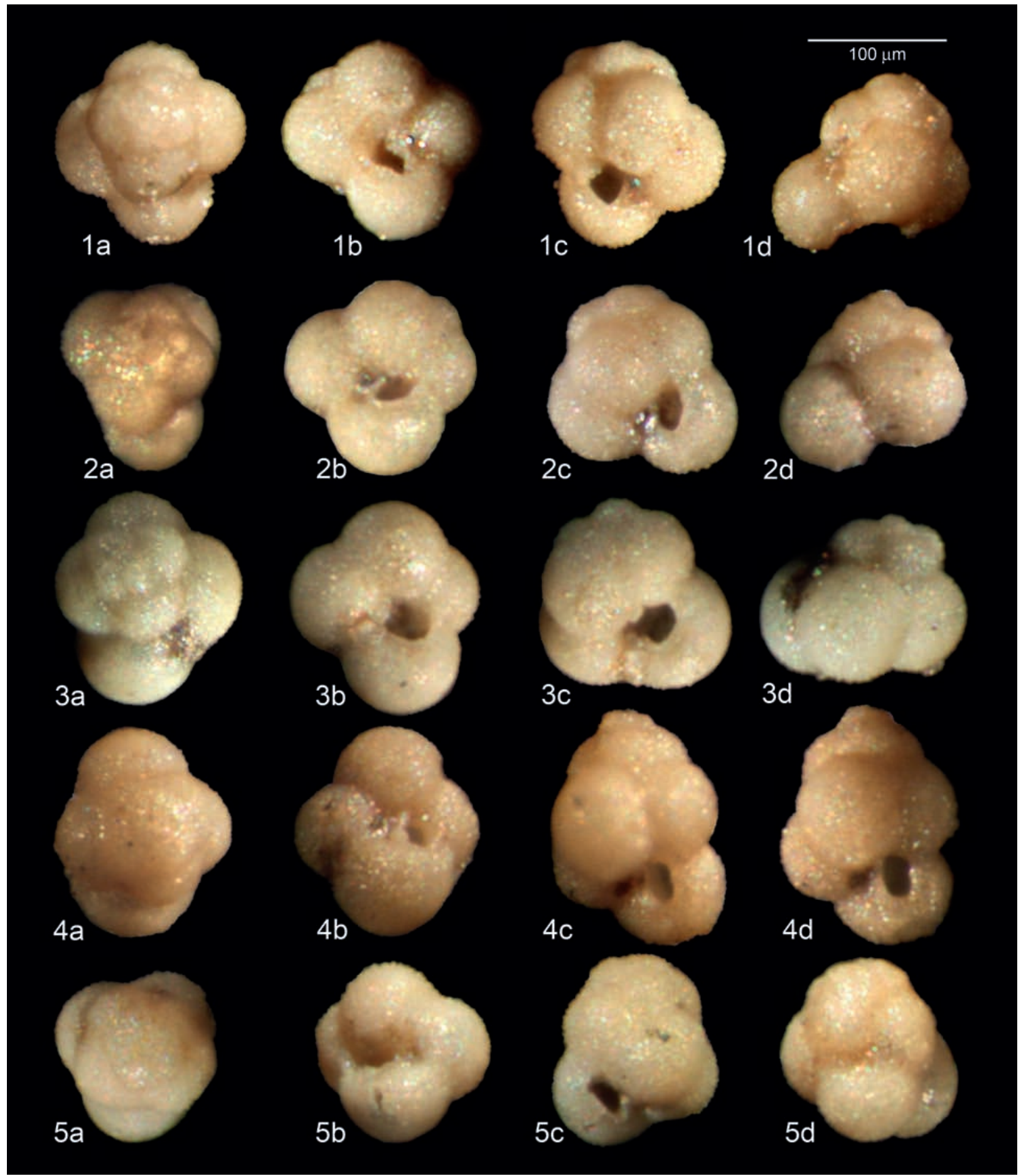

Explanation of Plate 1.

Type specimens of 'Globigerina bathoniana' Pazdrowa, 1969, coll. A-II-117/1.1-1.17, Muzeum Geologiczne ING PAN, Kraków. fig. 1. Holotype of 'Globigerina bathoniana', specimen DG-1 from the Middle Bathonian (Morrisi Chronozone) of Ogrodzieniec, Poland: 1a, spiral side (see Pazdrowa, 1969, fig. 1a); 1b, umbilical side (see Pazdrowa, 1969, fig. 1b); 1c, axial apertural view (see Pazdrowa, 1969, fig. 1c); 1d, axial abapertural view. fig. 2. 'G. bathoniana', paratype DG-2: 2a, spiral side (see Pazdrowa, 1969, fig. 2a); 2b, umbilical side (see Pazdrowa, 1969, fig. 2b); 2c, axial apertural view (see Pazdrowa, 1969, fig. 2c); 2d, axial abapertural view. fig. 3. 'G. bathoniana', paratype DG-3: 3a, spiral side (see Pazdrowa, 1969, fig. 3a); 3b, umbilical side (see Pazdrowa, 1969, fig. 3b); 3c, axial apertural view (see Pazdrowa, 1969, fig. 3c); 3d, axial abapertural view. fig. 4. 'G. bathoniana', paratype DG-11: 4a, spiral side; 4b, umbilical side; 4c-d, axial apertural views (see Pazdrowa, 1969, fig. 7). fig. 5. 'G. bathoniana', paratype DG-8: 5a, spiral side; 5b, umbilical side (see Pazdrowa, 1969, fig. 3b); 5c, axial apertural view (see Pazdrowa, 1969, fig. 8); 5d, axial abapertural view. Merged stack photographs in Photoshop CS4, Canon EOS 500D digital camera, SMZ 1500 Nikon stereomicroscope, normal reflected light. The orientation of many of the images follows Pazdrowa's illustrations to make comparisons with the originals easier. 


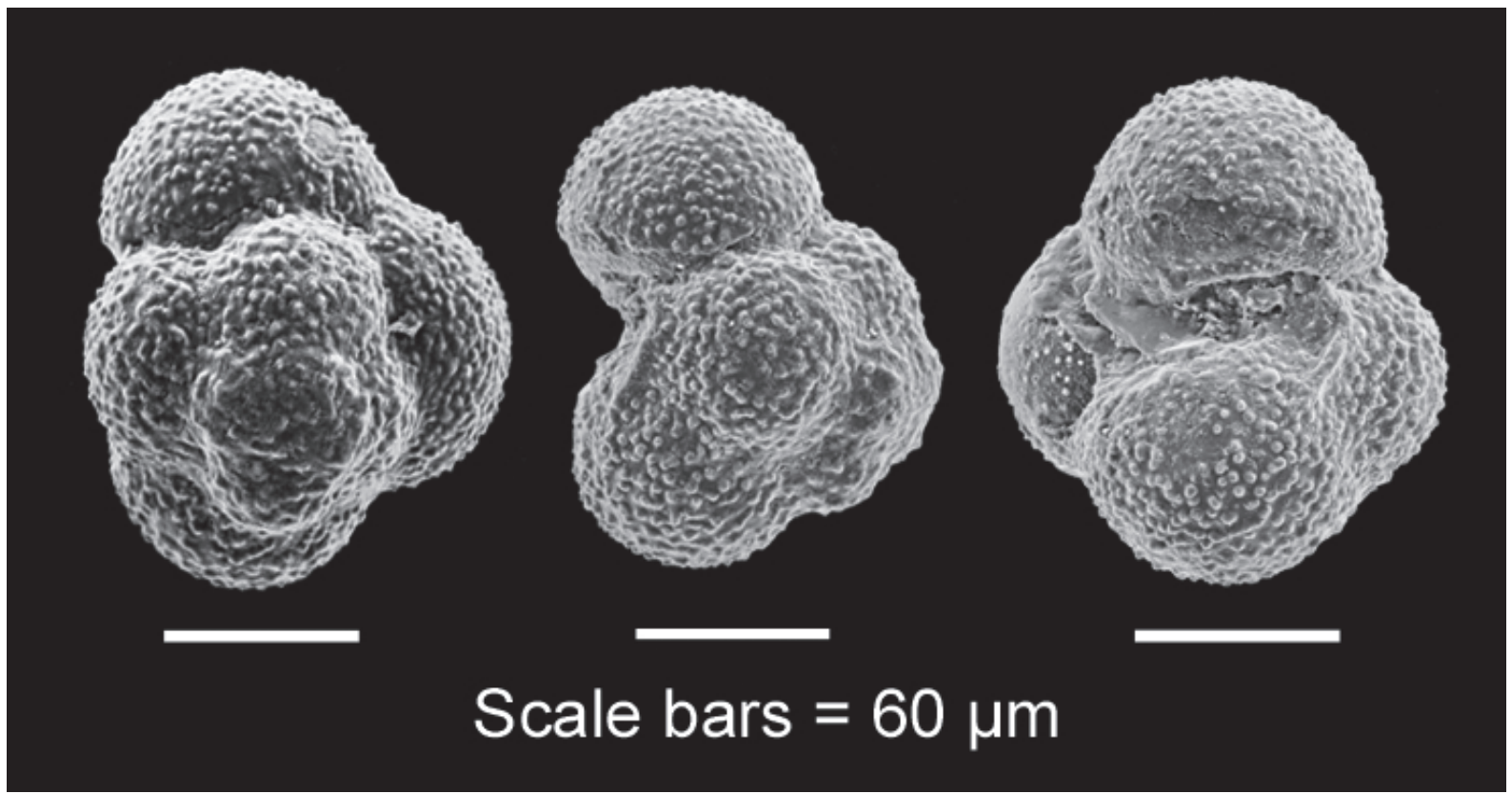

Explanation of Plate 2.

Metatype of 'Globigerina bathoniana' from the Middle Bathonian (Morrisi Chronozone) of Ogrodzieniec, Poland. This is a specimen from the collections of the Geological faculty of Moscow State University and was loaned to J. Whittaker (Natural History Museum, London) when Simmons et al. (1997) were preparing their volume on early planktic foraminifera.

(Simmons et al., 1997, pl. 2.8, fig. 12). These specimens provide Simmons et al. (1997) with the evidence for the inclusion of 'bathoniana' within the genus Globuligerina (Simmons et al., 1997, p. 27). This is taxonomically quite difficult and another review of the classification of Jurassic 'protoglobigerinids' is required. Fuchs (1973) recognized that there was a problem with the re-definition of this group by Bignot \& Guyader (1971) and he tried, unsuccessfully, to solve the problem with his new genus Polskanella. This genus was roundly repudiated by the community (e.g. Grigelis \& Gorbachik, 1980) and, in any case, was completely invalid as it was based on glauconitic internal moulds of planktic foraminifera with no trace of the test wall, external ornamentation or aperture.

The type species of Globuligerina (given by Simmons et al., 1997) is Globigerina oxfordiana Grigelis (1958) and the three views given by that author in the original figures (especially Grigelis, 1958, fig. 1c) show four gradually expanding chambers in the final whorl with an interiomarginal low arch for an aperture. Later, Grigelis (1985) re-figured the holotype, retaining the arch-shaped aperture but adding a bordering lip. Bignot \& Guyader (1966) illustrated forms of Globuligerina oxfordiana with more elongate chambers and a more loop-shaped aperture which looks very different to that figured by Grigelis in 1985 . These later interpretations of Globuligerina oxfordiana by Bignot \& Guyader $(1966,1971)$ are a significant problem according to Huddleston (1982). In a brief review of the taxonomy, Huddleston (1982, p. 637) argues that the majority of workers overlooked the fact that '... Bignot \& Guyader (1971) specifically designated Globuligerina oxfordiana Grigelis, 1958 emend. Bignot \& Guyader 1966, emend. 1971 and not Globigerina oxfordiana Grigelis 1958' as the type species of Globuligerina. If this is correct, then it calls into question the current interpretation of
G. oxfordiana (and, perhaps, its relationship with G. bathoniana) as well as the status of the genus Globuligerina. In their analysis of Globuligerina, Simmons et al. (1997) appear to have been unaware of the views presented by Huddleston (1982), which also attempted to deal with the genus Polskanella Fuchs and family Favusellidae. It should be noted that Stam (1986) also attempted a revision of Globuligerina, which was not fully endorsed by Simmons et al. (1997). Specimens with loop-shaped apertures are particularly seen in Oxfordian strata, but one cannot make this a restriction (even if that was wise) as a few of Pazdrowa's specimens of her Globigerina bathoniana have a loop-shaped aperture (P1. 1, fig. 4c, d). It is clear, however, that in planktic foraminifera the position, shape and form of the aperture is one of the defining features of the taxonomy and it would be unusual to demote it to a 'variable' in the Jurassic. One difficulty is, of course, the relatively limited occurrence and distribution of Jurassic taxa and this makes it difficult to establish a definitive phylogeny for the species involved. Our view, for the present, is that we should regard 'bathoniana' as an early form of Conoglobigerina pending a further reassessment of the taxonomy (which is on-going).

The material that Fuchs (1973) used to propose the new genus Polskanella came from the Ogrodzieniec Glauconitic Marl Formation (Wierzbowski et al., 2006) attributed to the Callovian (Matyja \& Głowniak, 2003; Barski et al., 2004) and this has been re-sampled by us as part of a wider re-investigation of Polish Jurassic planktonic foraminifera (Fig. 1).

\section{PLANKTIC FORAMINIFERA FROM THE OGRODZIENIEC GLAUCONITIC MARL FORMATION}

The samples used by Fuchs were collected by M. Schmidt during a field excursion to Poland (European Micropalaeontological Colloquium, 1967). The field guide for that excursion provides a 
detailed record of the foraminifera recorded in the mid-Upper Jurassic succession of the Ogrodzieniec area (Bielecka \& Styk, 1967, fig. 29). In this range chart the only planktic foraminifera are recorded as Globigerina cf. helveto-jurassica, another of the taxa described in detail by Simmons et al. (1997) as Haeuslerina helvetojurassica (Haeusler, 1881). This is a low-spired form with an intraumbilical-extraumbilical aperture and clearly depressed sutures. Within the processed residues of the Ogrodzieniec Glauconitic Marl Formation one finds exceptionally high numbers of planktic foraminifera in the form of 'Glaukonitkern' (glauconitic internal moulds) and some of these (see Pl. 3) are low-spired forms comparable to $H$. helvetojurassica and almost certainly the forms being recorded by Bielecka \& Styk (1967) in the field guide range chart. Also present are large numbers of high-spired Conoglobigerina, some of which have very pointed tests. Other forms are lower spired with the very characteristic four chambers in the final whorl of both Conoglobigerina and Globuligerina. With no trace of the original wall, surface ornament and aperture, a generic determination is impossible, although it is noticeable that all of these forms grade imperceptibly into one another when viewed in this mode of preservation. Within these samples are examples of benthic foraminifera (probably Epistomina) and other agglomerations of 'chambers' that Fuchs (1973) used to generate several new genera (all invalid).

It is interesting to note that planktic foraminifera from the Ogrodzieniec Glauconitic Marl Formation show a style of preservation very like that illustrated for Globuligerina calloviensis Kuznetsova, even though Simmons et al. (1997, pp. 27-28) indicate that, despite appearances, the original wall is preserved. Some of the specimens found by us in the Ogrodzieniec Glauconitic Marl Formation are almost certainly G. calloviensis, providing evidence of further complications in the taxonomy at this stratigraphical level. The complete assemblage of planktic foraminifera from the Ogrodzieniec Glauconitic Marl Formation is the subject of on-going research, together with material from the same stratigraphical interval collected from the Holy Cross Mountains near Kielce (Poland).

It has previously been noted (Hudson et al., 2009) that there is a widespread (Poland, Germany, UK, etc.) occurrence of planktic foraminifera in the uppermost Callovian to lowermost Oxfordian (e.g. Riegraf, 1987). This appears to be a genuine level of abundance rather than a sampling artefact. Recent investigations of Jurassic climates are suggestive of a cooler interval at the Callovian-Oxfordian transition, the evidence coming from:

- presence of glendonites, drop stones and other 'cool climate' indicators (Chumakov \& Frakes, 1997; Price, 1999);

- ammonite migrations (e.g. Fortwengler, 1989); and

- climatic information arising from investigations of stomatal densities in leaves (see a summary of stomatal and other data in Royer, 2006).

While some interpretations (Hesselbo \& Coe, 2000; Pearce et al., 2005) show a highstand in the Early Oxfordian (Mariae Chronozone), the climatic evidence (Chumakov \& Frakes, 1997; Tremolada et al., 2006) suggests a cooling around the CallovianOxfordian boundary and, perhaps, the presence of polar ice. This evidence indicates that temperatures began to fall (in Europe) in the latest Callovian (Athleta Chronozone) and lasted into the earliest
Oxfordian (Dromart et al., 2003; Martin-Garin et al., 2010). The stable isotope data from belemnite guards indicate a cooling of some $6-7^{\circ} \mathrm{C}$ in Russia, Poland and the UK (Podlaha et al., 1998; Barskov \& Kiyashko, 2000; Jenkyns et al., 2002; Wierzbowski \& Rogov, 2011). Further evidence of a cooling at this time comes from cool gymnosperm floras in the Upper Callovian and Lower Oxfordian of Germany and France (Philippe \& Thevenard, 1996) and palynomorphs of cool aspect in the North Sea Basin (Abbink et al., 2001). Barski et al. (2004) also interpret cooling at the Bathonian/Callovian boundary based on the change in the dinoflagellate assemblage from the Ogrodzieniec quarry. Wierzbowski \& Joachimski (2007) record the lowest temperatures in the Late Bajocian and Bathonian $\left(c .9^{\circ} \mathrm{C}\right)$, with gradual warming in the Callovian and Oxfordian (Wierzbowski et al., 2009). The most striking feature appears to be an influx of 'Boreal' ammonites (cardioceratids and kosmoceratids) in southeastern France (e.g. Fortwengler, 1989) and elsewhere in NW Europe (K. Page, pers. comm., 2010). The palaeogeography of the time (see Hudson et al., 2009, figs 6, 8) certainly shows a connection between the UK, France, Germany, Poland and areas in Russia, such as the Pechora Basin, from which Compactogerina stellapolaris (Grigelis in Grigelis et al., 1977) was first described. As noted by Simmons et al. (1997, p. 29), this species has a thickened wall and apertural covering reminiscent of modern cool-water taxa, such as Neogloboquadrina pachydrma (Ehrenberg, 1894). Hart et al. (2007) have recorded C. stellapolaris from the Mariae Chronozone in Oxford Clay Formation of Dorset, an occurrence which appears to confirm the north-south ammonite migrations.

If there was a cooling, associated with a lowering of atmospheric $\mathrm{pCO}_{2}$ then this may have had an impact on oceanic $\mathrm{pH}$. The Jurassic planktic foraminifera, with their aragonitic wall structure (Kolodziej et al., 2011), may well have been more susceptible to dissolution as a result of a changing $p \mathrm{CO}_{2}$ and this abundance of planktic taxa in the latest Callovian to earliest Oxfordian is a preservation signal, comparable to that found in the Late Pleistocene with the preservation of aragonitic pteropods being enhanced in the glacial episodes and reduced in the interglacials (Messenger et al., 2010; Wall-Palmer et al., 2011).

\section{JURASSIC 'FORAMINIFERAL OOZE'}

Modern Foraminiferal Ooze (Murray \& Renard, 1891) or Carbonate Ooze occupies a particular environmental niche in the oceans of the present day. In terms of water depth it lies between the Pteropod Ooze (Pelseneer, 1888) of tropical shallow waters that are deposited above the Aragonite Compensation Depth (ACD) and the deeperwater sediments deposited beneath the carbonate lysocline (Kennett, 1982) which are often characterized by clays, radiolarian tests and other remains of non-carbonate faunas/floras. Such pelagic sediments are less commonly encountered in the oceanic geological record, becoming less common in the Palaeogene than in the Neogene (Kennett, 1982). In the Cenozoic of the Carpathians (Blaicher, 1967; Olszewska, 1983, 1984), the 'Globigerina Marls' contain $70 \%$ up to $100 \%$ planktic foraminiferal assemblages of latest Eocene taxa and clearly represent an analogue of the modern Carbonate Ooze deposited in a unique tectonic setting.

In the Cretaceous, the chalk facies (Hancock, 1976) of NW Europe is well known as a pelagic carbonate but it is certainly nothing like modern Carbonate Ooze. In the UK succession of southeast England planktic foraminifera rarely exceed $50 \%$ of the 


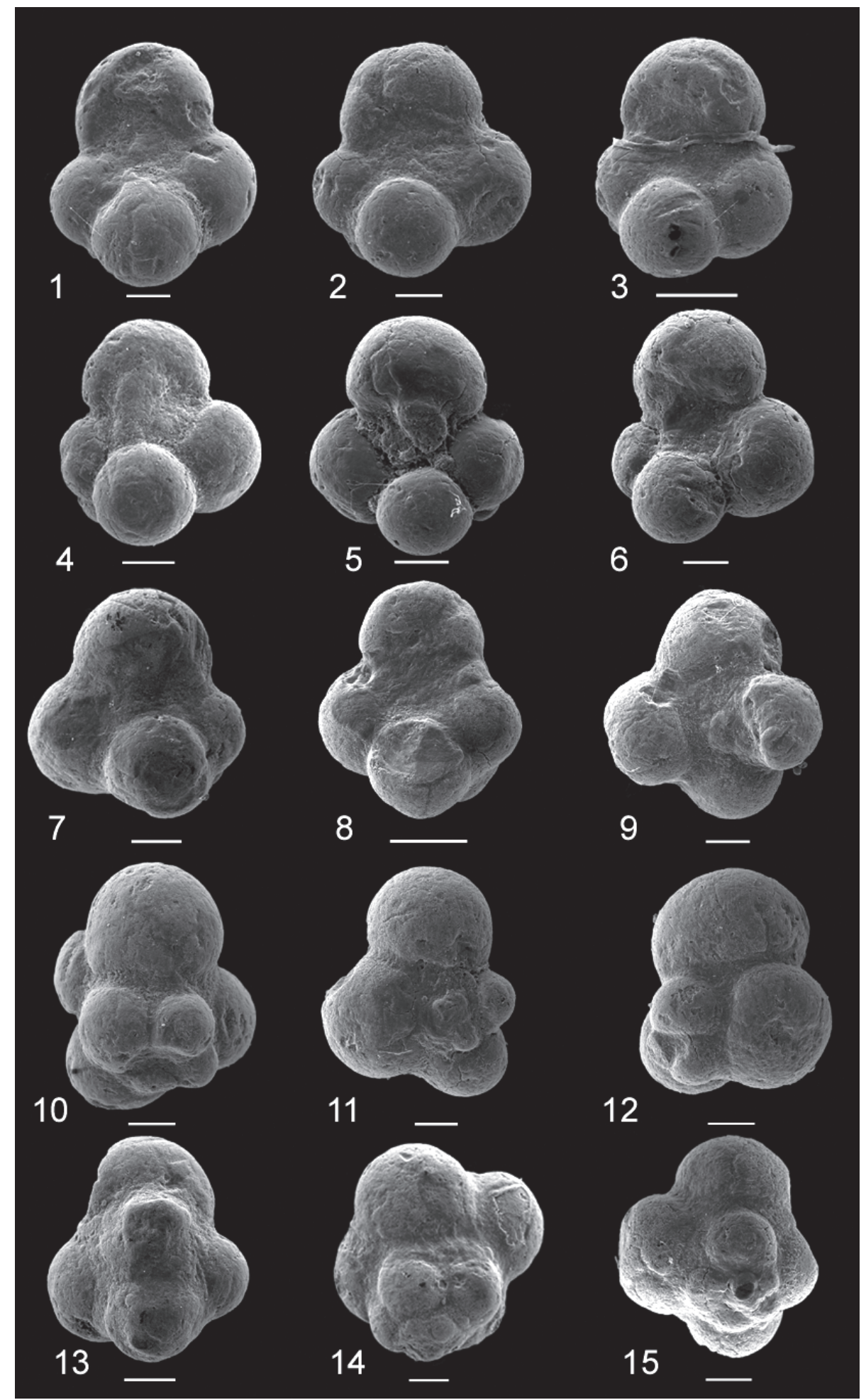

Explanation of Plate 3.

Planktic foraminifera from the Ogrodzieniec Glauconitic Marl Formation, uppermost Callovian. Identifications are tenuous, being based only on the internal glauconitic moulds that characterize the assemblage. figs 1-5. Conoglobigerina oxfordiana (Grigelis, 1958). fig. 6. Conoglobigerina calloviensis (Kuznetsova in Kuznetsova \& Uspenskaya, 1980). figs 7, 9. Conoglobigerina sp. cf. C. calloviensis (Kuznetsova in Kuznetsova \& Uspenskaya, 1980). fig. 8. Conoglobigerina sp. cf. C. oxfordiana Grigelis. fig. 10. Conoglobigerina sp. cf. C. bathoniana (Pazdrowa). fig. 11. Haeuslerina sp. cf. H. helvetojurassica (Haeusler, 1881). figs 12-15. Conoglobigerina bathoniana (Pazdrowa). Scale bars are $50 \mu \mathrm{m}$, except figs 3,8 which are $100 \mu \mathrm{m}$. This material is currently in the collections of the University of Plymouth pending deposition in the Geological Museum of the Institute of Geological Sciences, Polish Academy of Sciences, Kraków. 


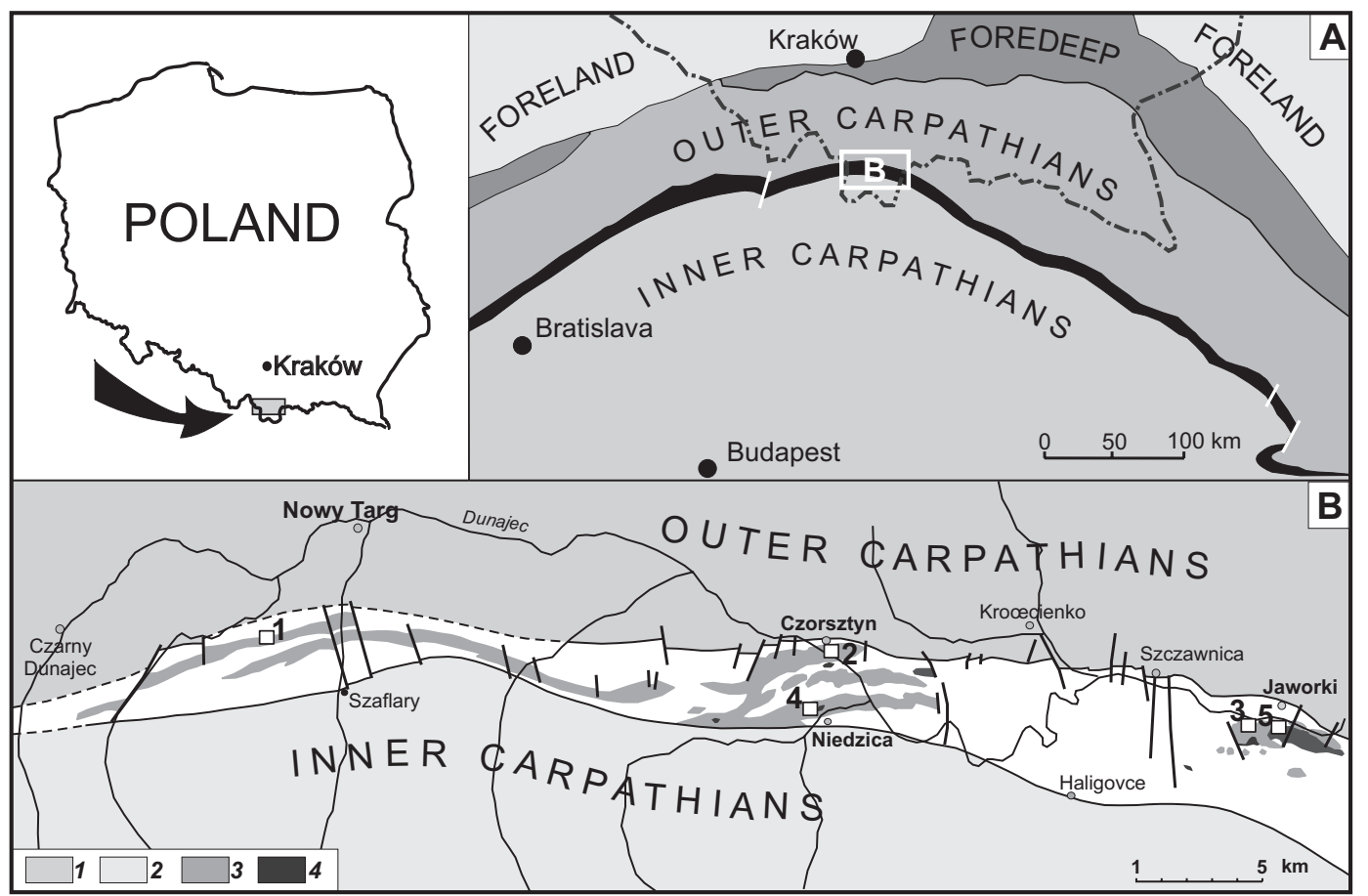

Fig. 2. (A) Location of the Pieniny Klippen Belt (in black) within the Carpathians. (B) Location of the studied sections of the Pieniny Klippen Belt in Poland (base map simplified from Birkenmajer, 1963, 1977). 1, Magura Palaeogene flysch (Magura Nappe); 2, Podhale Palaeogene flysch (autochthonous); 3, Czorsztyn Succession (1, Stankowa Skała; 2, Czorsztyn Castle Klippe; 3, Krupianka Creek); 4, Niedzica Sucession (4, Niedzica Podmajerz Klippe); 5, Czajakowa Skała). Note that the Ogrodzieniec/Częstochowa area is located $60 \mathrm{~km}$ northwest of Kraków in the area indicated on the map as 'Foreland' (see Fig. 1).

500-125 $\mu \mathrm{m}$ assemblage, and then only in the lower to midTuronian (Hart \& Bailey, 1979; Hart, 2008). In the Cenomanian or the Coniacian-Campanian of southeast England the planktic: benthic ratio ranges between 5: 95 and 40: 60 in counts based on the $500-125 \mu \mathrm{m}$ size fraction (higher planktic values if using the 125-63 $\mu \mathrm{m}$ size fraction as this will include many more juvenile forms). Higher planktic:benthic ratios are recorded in parts of East Anglia and the North Sea Basin (Bailey, pers. comm., 2010) and this is almost certainly the result of increased water depth, although calculating water depth for a given planktic: benthic ratio remains elusive (or impossible). The figures for the Cretaceous are normally below the levels normally recorded in modern Carbonate Ooze. In the deep sea sediments of Cretaceous age there are assemblages (e.g. Leckie 1985, 1987; Petrizzo \& Huber, 2006) more closely approaching those of the Carbonate Ooze and, in the oceanic basins of the Cretaceous deep sea, sediments are often unfossiliferous red clays (Hu et al., 2005) devoid of planktic foraminifera.

In the Czorsztyn Limestone Formation (Birkenmajer, 1977; Hudson et al., 2005) of southern Poland, the limestones of the Pieniny Klippen Belt (Birkenmajer, 1963, 1977, 1986; Krobicki \& Wierzbowski, 2004; Lewandowski et al., 2005; Fig. 2) contain an assemblage of foraminifera that is very close to being $99 \%$ planktic (Pl. 4). The sediments, which are dated as Bathonian-Oxfordian by means of ammonites (Wierzbowski et al., 1999), contain only occasional benthic foraminifera, rare microforaminifera (Mišík \& Soták, 1998) and occasional shell fragments (= filaments) of Bositra. The 'paper pecten' Bositra buchi (Roemer, 1836) has been described (Tyszka, 1994, 1999, and unpublished data) from black shales in the 'deeper' parts of the Pieniny Klippen Basin as a benthic taxon. Etter (1996) also interprets Bositra buchi from the Aalenian Opalinum Clay as 'truly benthic and probably byssally attached to the substrate'. He assumes a benthic mode of life 'based on the bell-shaped abundance distribution along an oxygenation gradient and nearest-neighbour spatial analysis' (Etter, 1996, p. 325). In the Oxford Clay Formation of the UK, Bositra buchi is thought to have been a pendant form (Duff, 1975), attached to algae or floating wood, although Jefferies \& Minton (1965) and Oschmann (1994) have suggested that it is pseudo-planktic. The association of this taxon with assemblages dominated by planktic foraminifera in the Pieniny Klippen Belt (Wierzbowski et al., 1999) and its presence (Steiner et al., 1998) in the hemi-pelagic sediments of Fuerteventura (Atlantic Ocean) are indicative of a more planktic mode of life, perhaps analogous to the modern pteropods (holoplanktic gastropods). Thin sections from these Polish limestones yield almost no detrital grains although, with the matrix now recrystallized, it is impossible to comment on the initial nature of the sediment. Described as a Globuligerina packstone, this Jurassic assemblage is almost monospecific, containing Globuligerina bathoniana (or G. oxfordiana) (Hudson et al., 2005; Sidorczuk, 2005). Using acetolysis (acetic acid digestion), Wernli \& Görög (1999) have isolated comparable faunas from the Bakony Mountains in Hungary and, again, figured taxa with a range of apertural shapes. While the apparently monospecific nature of these Polish foraminiferal packstones makes them rather unusual, this is to be expected at a point in the geological succession where the evolution of the planktic foraminifera was just beginning. Modern Carbonate Ooze relies on the production of tests at the 


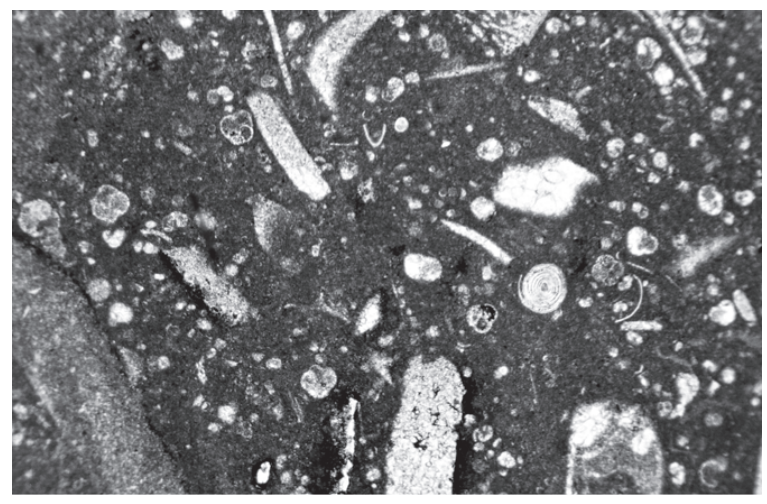

A

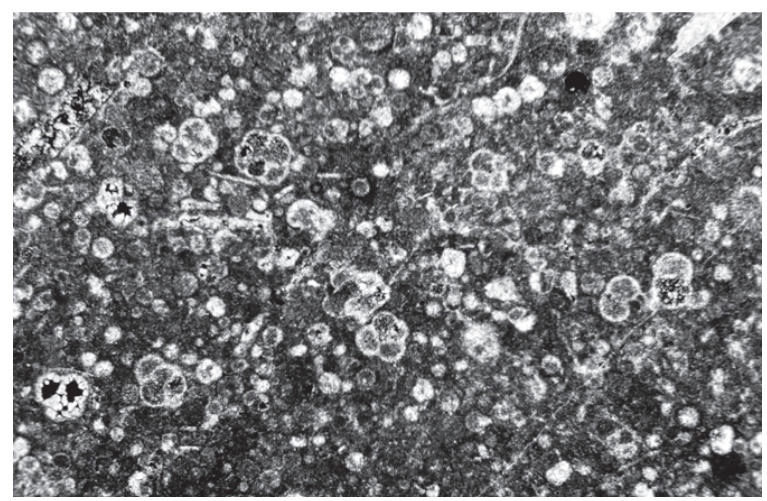

\section{C}

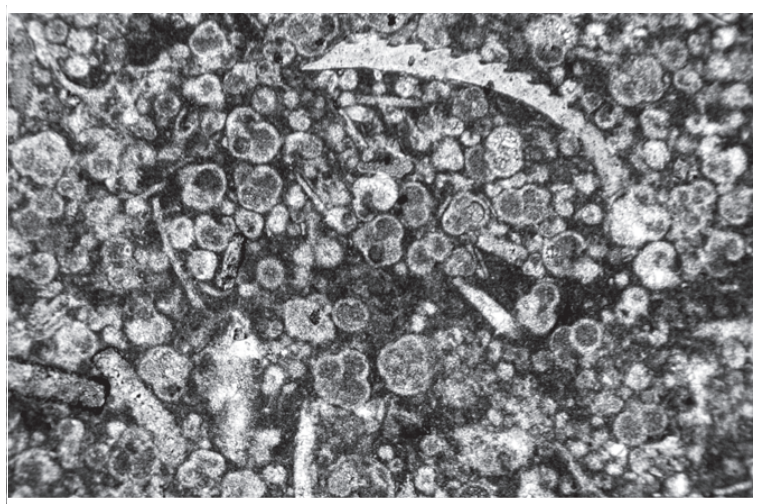

E

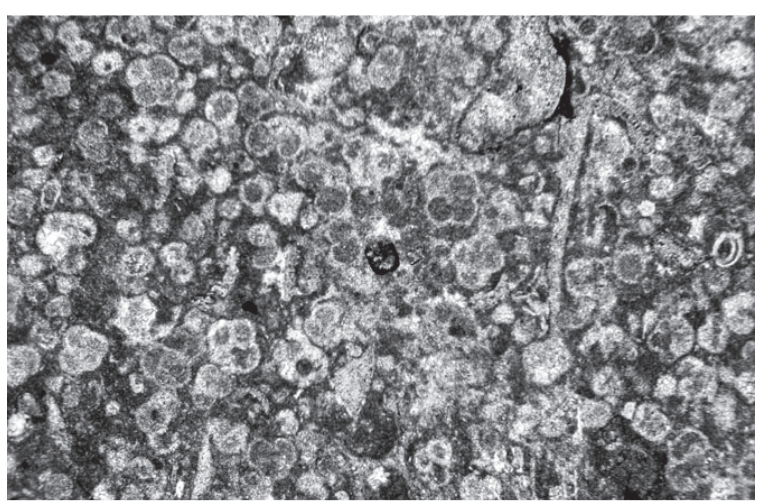

G

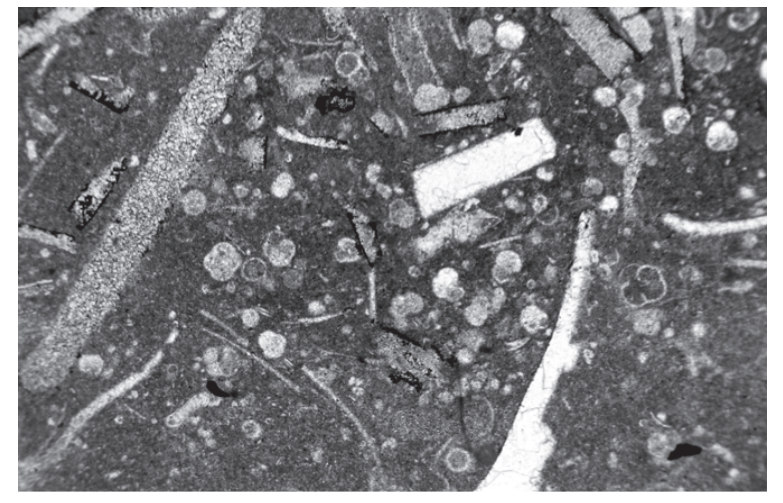

B

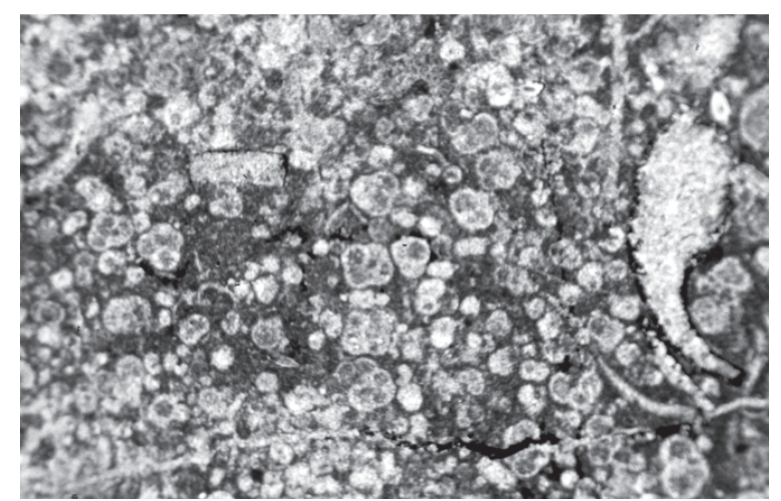

D

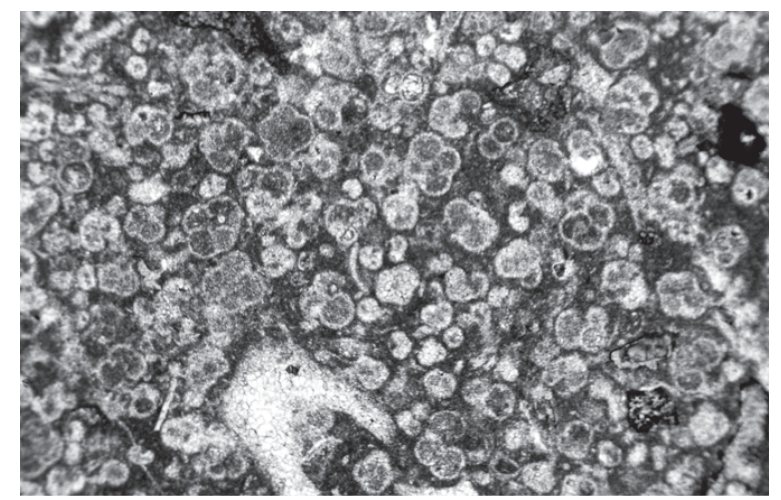
F

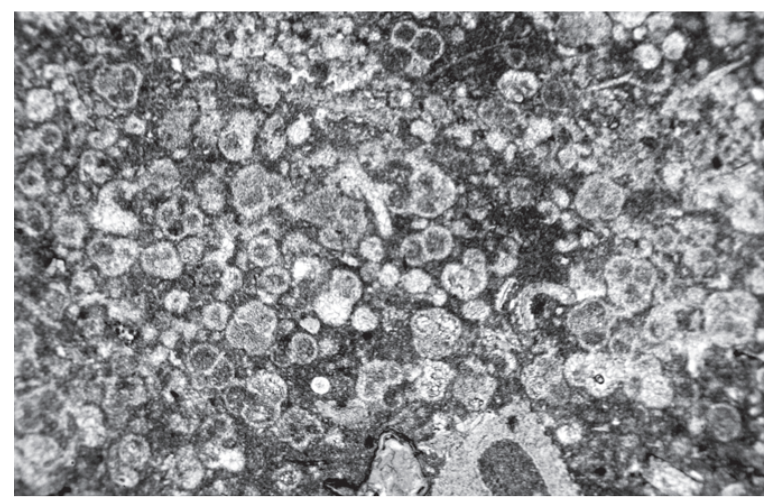
H 
various levels in the water column (Bé, 1977) in which the modern taxa are known to live. In the Jurassic the situation must have been quite different as the depth partitioning of the planktic foraminifera is probably a feature of the post mid-Cretaceous (Hart \& Bailey, 1979; Hart, 1980, 1999; Caron \& Homewood, 1983).

In the limestones of Middle and Late Jurassic age in southern Poland (Wierzbowski et al., 1999; Hudson et al., 2005; Sidorczuk, 2005; see Fig. 2), in other parts of the Carpathian Mountains and in many of the pelagic limestones of Bajocian/Bathonian age in central Europe (see Hudson et al., 2009, figs 3, 5) there are many records of foraminifera-rich packstones where the assemblage is $>95 \%$ that of planktic taxa. In thin section these frequently show the characteristic four-chambered appearance of Conoglobigerina or Globuligerina and, in thin section, the various genera and species are impossible to differentiate with confidence. Using acetolysis Wernli \& Görög (1999) have successfully isolated the planktic foraminifera and identified the taxa at the species level. In southern Poland we have studied the assemblages only in thin section (Pl. 4) as attempts at acetolysis proved somewhat unsuccessful. Often described as being of 'ammonitico rosso' type, these sediments are restricted to the submarine swells while the intervening, more basinal areas are characterized by radiolarites (e.g. Czajakowa Radiolarite Formation of the Niedzica Branisko and Pieniny successions; see Birkenmajer (1977, 1986), Hudson et al. (2005) and Tyszka (1999). In many parts of the Carpathian Mountains in southern Poland exposures are limited and the geological structures quite complex. It is almost impossible to construct a single lithological log against which to plot the micropalaeontological data. Each nappe has its own characteristic succession and comparison between nappes is often difficult. All the localities mentioned here are discussed more fully by Wierzbowski et al. (1999, 2006).

Similar sediments, with comparable numbers of planktic foraminifera, have been described from the Bajocian limestones of the Bakony Mountains (Hungary) (Wernli \& Görög, 1999, 2000) where they contain a slightly more diverse assemblage ( $\sim$ taxa). These assemblages also have a reduced $(\sim 1 \%)$ benthic assemblage. In these successions, however, many of the planktic taxa have a thin wall, while some appear to have a wall that is twice the thickness. This feature has been interpreted by Görög \& Wernli (2003) as secondary thickening, much as is seen today in Truncorotalia truncatulinoides (d'Orbigny, 1839). An alternative view would be that these forms with different wall thicknesses represent dimorphism within the early planktic foraminifera, although this is thought to be unlikely. While this thickening has been recorded in Hungary (Görög \& Wernli, 2003) and Greece (Baumgartner, 1985), we have not seen this in samples from Poland, Spain and northern Italy.
The depositional environment of these limestones is quite poorly understood as their present location is within a complex tectonic unit in the Carpathian Orogenic Belt (Wierzbowski et al., 1999; Sidorczuk, 2005; Sidorczuk \& Nejbert, 2008). The Czorstyn Ridge (Tyszka, 1994; Golonka \& Krobicki, 2001; Krobicki \& Wierzbowski, 2004) formed in the Pieniny Klippen Basin during the early Bajocian (Wierzbowski et al., 1999). It was a long-lived submarine pelagic swell onto which these Conoglobigerina/Globuligerina-rich sediments were deposited. The source of Pazdrowa's material is the clay succession of the Morrisi Chronozone from the Ogrodzieniec/ Częstochowa area, which lies to the northwest of Krakow and in a Middle Jurassic mid-shelf succession (Fig. 2). These clays contain abundant benthic foraminifera, ostracods and holothurian sclerites and represent a completely different depositional environment (Gedl et al., 2003; Smoleń, in press).

\section{THE ARAGONITE II OCEAN}

These Middle Jurassic Globuligerina (or Conoglobigerina) packstones appear to occupy the position in which one would expect to find the ancient analogue of the modern Carbonate Ooze, especially if accentuated by winnowing on submarine 'highs'. Their preservation, however, is also function of water depth and the position of the Aragonite Compensation Depth (ACD) and Carbonate Compensation Depth (CCD) - and their associated lysoclines (ALy, CLy) - in the water column. The positions of the ACD and CCD in the water column are a function of the near-surface productivity of the organisms providing the carbonate and the water chemistry causing dissolution at depth. In the modern ocean there is a diverse assemblage of calcareous nannofossils, calcareous dinoflagellates, planktic foraminifera and pteropods in the upper levels of the water column, all of which act to depress the ACD and CCD.

In the mid-Jurassic the situation was very different and the positions of the ACD and CCD were, almost certainly, completely different. The pteropods had not evolved and the planktic foraminifera probably evolved in the Toarcian (Hart et al., 2003; Hudson et al., 2009), and remained a low diversity assemblage until the earliest Cretaceous (Hart et al., 2002). These early planktic foraminifera were aragonitic in composition (Simmons et al., 1997) and this is in keeping with an origin within the Aragonite 11 Ocean of Stanley \& Hardie (1998), Stanley (2006) and De Vargas et al. (2007). The earliest planktic foraminiferid, Conoglobigerina, probably evolved from the Oberhauserella-Praegubkinella lineage (Wernli, 1988, 1995) which is also typified by aragonitic tests. Other groups of foraminifera appearing in the Aragonite 11 Ocean include the Involutinina and Robertinina (see Martin, 1995), although Martin (1995, fig. 2) incorrectly indicates that the

\section{Explanation of Plate 4.}

Representative thin section photomigrographs of Jurassic planktic foraminifera from the Pieniny Klippen Belt of Southern Poland. All images have a field of view of $6 \mathrm{~mm}$. A. Stankowa Skała, Czorsztyn Limestone Formation, Oxfordian, scattered sections of Conoglobigerina (or Globuligerina) with rare benthic foraminifera. B. Stankowa Skała, Czorsztyn Limestone Formation, Oxfordian, sections through Conoglobigerina (or Globuligerina) with rare sections through 'filaments' of Bositra. C. Stankowa Skała, Czorsztyn Limestone Formation, Oxfordian, sections through Conoglobigerina (or Globuligerina) showing the characteristic four chambers in the final whorl. D. Czorsztyn Castle Klippe (Bed 5), Czorsztyn Limestone Formation, Oxfordian, Conoglobigerina (or Globuligerina) packstone. E, F. Czorsztyn Castle Klippe (Bed 5), Czorsztyn Limestone Formation, Oxfordian, Conoglobigerina (or Globuligerina) packstone with abundant sections through forms with four chambers in the final whorl. G, H. Krupianka Creek (Bed 6), Czorsztyn Limestone Formation, Lower Kimmeridgian, Conoglobigerina (or Globuligerina) packstone. Some of the thin sections are currently stored in the University of Plymouth while the original rocks and other thin sections are in the Geological Collections of the University of Warsaw. 
earliest Globigerinina appeared in the latest Triassic with calcareous tests. Over the last four years we have, systematically, studied the collections of Oberhauser (1960) and Fuchs (1967, 1970, 1973 ) in the Geologische Bundesanstalt in Vienna and have concluded that these Triassic and Early Jurassic forms are benthic in character and that the origin of the planktic foraminifera was almost certainly in the Early Jurassic (and not the Triassic as suggested by Fuchs (1967)).

The other newly evolved calcareous taxa (coccoliths, calcareous dinoflagellates and scleractinian corals) appeared in the highly oversaturated seas of the Triassic (Ridgwell, 2005; Ridgwell \& Zeebe, 2005). The Triassic coccoliths (heterococcoliths) had simple murolith morphologies (Bown et al., 2004; Bown, 2005), were very small $(2-3 \mu \mathrm{m})$ and were at the lower limit of preservation potential (Young et al., 2005). The earliest holococcoliths (Erba, 2006; De Vargas et al., 2007, fig. 4) were mid-Toarcian in age, which is approximately the same time as the planktic foraminifera may have evolved from benthic ancestors. These early nannoplankton, however, appear to have been more associated with shelf and epeiric environments throughout most of the Jurassic, only becoming part of the open ocean plankton in the late Jurassic (Falkowski et al., 2004; Katz et al., 2004, 2007; De Vargas et al., 2007, p. 277).

Evolving from benthic ancestors in the mid-Toarcian, the planktic foraminifera dispersed rapidly within the Jurassic Tethys/PeriTethys seaway (Hudson et al., 2009). In many areas of this seaway the low-diversity planktic foraminiferal assemblage was almost the only provider of $\mathrm{CaCO}_{3}$ (in the form of aragonite) to the sea floor. If this is true, then how can the models of the ACD and CCD (and associated ALy and CLy) show no change in depth between the lowermost-Upper Jurassic (see, for example, Bosellini \& Winterer, 1975)? If the principal (or even only) carbonate producer appears in the Toarcian, and requires some time to disperse throughout Tethys/Peri-Tethys, then one might expect to see a shallow ACD/ $\mathrm{CCD}$ in the earliest Jurassic migrate downwards in the water column during the mid-Upper Jurassic (Garrison \& Fischer, 1969). As the planktic foraminifera had aragonitic tests during this interval and, prior to the migration of the holococcoliths into the open ocean, there was little if any calcitic plankton, then the ACD and the CCD may almost have been co-located in the water column. This conclusion would have significant implications for the interpretation of marine, deeper-water carbonates during the Jurassic. All we can say, at present, is that these foraminiferal packstones with a >99: 1 planktic: benthic ratio clearly indicate sedimentation above the ALy (and ACD) at a depth which is presently unspecified. The models of Bosellini \& Winterer (1975, fig. 2) suggest that this may have been shallower than $1000 \mathrm{~m}$ in the Bajocian to Oxfordian interval and our palaeontological information is suggestive of only a few hundred metres at most.

\section{SUMMARY}

The simple separation of Globuligerina from Conoglobigerina on the basis of a loop-shaped aperture (Simmons et al., 1997) is almost unworkable. Conoglobigerina bathoniana (Pazdrowa) is a key species in this debate as it shows that, even as early as the Middle Bathonian, the ratio of arch to loop-shaped aperture varies within one assemblage and that a consistent (and 'comfortable') separation is impossible. The successions in southern Poland are quite critical in this regard as they are:
- rich in planktic foraminifera;

- have a well-constrained ammonite stratigraphy for reliable age determinations; and

- contain assemblages with both internal and external features preserved.

As more information comes to light about the mid-Late Jurassic plankton we are learning more about the nature of the Jurassic oceans and the evolution of this plankton in the Aragonite 11 ocean. The unresolved issue for those working on Mesozoic planktic foraminifera remains, however, their evolution in the latest Jurassic and post-Jurassic calcitic ocean where all taxa appear to have calcitic tests.

\section{ACKNOWLEDGEMENTS}

Sincere thanks are extended to Mrs Barbara Kielińska-Michalik, Head of the Geological Museum of the Institute of Geological Sciences, Polish Academy of Sciences in Kraków, who provided access to the complete collection of Pazdrowa's material, together with microscope facilities for their study by $\mathrm{MBH}$ in September 2009. The authors thank Prof. Danuta Peryt (Warsaw) for providing a copy of the European Micropalaeontology Colloquium Field Guide for Southern Poland and Dr Holger Gebhardt (Vienna) for facilitating access to the collections of the Geological Survey of Austria. The authors have also benefitted from discussions on this subject with Dr Agnes Görög (Budapest), Prof. Roland Wernli (Geneva), Dr Mike Simmons (Neftex), Dr Kevin Page (Plymouth University) and Dr John Whittaker (Natural History Museum, London). Drs Bridget Wade (Leeds University) and Robert Campbell (Shell Exploration and Production, Rijswijk, Netherlands) are thanked for their helpful and constructive reviews of this paper.

\section{Manuscript received 26 May 2011 \\ Manuscript accepted 6 September 2011}

Scientific Editing by Alan Lord

\section{REFERENCES}

Abbink, O., Targarona, J., Brinkhuis, H. \& Visscher, H. 2001. Late Jurassic to earliest Cretaceous palaeoclimate evolution of the southern North Sea. Global Planetary Change, 30: 231-256.

Barski, M., Dembicz, K. \& Praszkier, T. 2004. Biostratigraphy and the Mid-Jurassic environment from the Ogrodzieniec Quarry [in Polish with English abstract]. Tomy Jurajskie, 2: 61-68.

Barskov, I.S. \& Kiyashko, S.I. 2000. Thermal regime variations in the Jurassic marine basin of the East European Platform at the Callovian/ Oxfordian boundary: evidence from stable isotopes in belemnite rostra. Doklady Earth Sciences, 372: 643-645.

Baumgartner, P.O. 1985. Jurassic sedimentary evolution and nappe emplacement in the Argolis Peninsula (Peloponnesus, Greece). Mémoires de la Société Helvétique des Sciences Naturelles, 99: 1-111.

Bé, A.W.H. 1977. An ecological, zoogeographic and taxonomic review of Recent Planktonic Foraminifera. In Ramsay, A.T.S. (Ed.), Oceanic Micropalaeontology, Academic Press, London, 1: 1-100.

Bielecka, W. \& Styk, O. 1967. The Callovian and Oxfordian in the vicinity of Ogrodzieniec. In Część, I. (Ed.), X Europejskie Kolokwium Mikropaleontologiczne w Polsce - 1967. Instytut Geologiczny Biuletyn, 211: $128-142$.

Bignot, G. \& Guyader, J. 1966. Découverte de foraminifers planctoniques dans l'Oxfordien du Havre (Seine-Maritime). Revue de Micropaléontologie, 9: 104-110.

Bignot, G. \& Guyader, J. 1971. Observations nouvelles sur Globigerina oxfordiana Grigelis. In Farinacci, A. (Ed.), Proceedings of the Second 
Planktonic Conference, Roma 1970. Edizioni Tecnoscienza, Rome, 1: 79-81.

Bignot, G. \& Janin, M.-C. 1984. Découverte de Globuligerina oxfordiana (Foraminifère planctonique) dans le Bajocien stratotype de la Falaise des Hachettes (Saint-Honorine-des-Pertes, Calvados, France). Compte Rendu Hebdomadaire des Séances de l'Académie des Sciences, Paris, Série 2, 298: 751-756.

Birkenmajer, K. 1963. Stratigraphy and paleogeography of the Czorsztyn series (Pieniny Klippen Belt, Carpathians) in Poland. Studia Geologica Polonica, 9: 1-380.

Birkenmajer, K. 1977. Jurassic and Cretaceous lithostratigraphic units of the Pieniny Klippen Belt, Carpathians, Poland. Studia Geologica Polonica, 45: 1-158.

Birkenmajer, K. 1986. Stages of structural evolution of the Pieniny Klippen Belt, Carpathians. Studia Geologica Polonica, 88: 7-32.

Blaicher, J. 1967. Assemblages of small foraminifera from the SubMenilite Globigerina Marls in the Carpathians. In The Xth European Micropalaeontological Colloquium in Poland - 1967. Biuletyn Instytut Geologiczny, 211: 355-363.

Bosellini, A. \& Winterer, E.L. 1975. Pelagic limestone and radiolarite of the Tethyan Mesozoic: a genetic model. Geology, 3: 279-282.

Bown, P.R. 2005. Calcareous nannoplankton evolution: a tale of two oceans. Micropaleontology, 51: 299-308.

Bown, P.R., Lees, J.A. \& Young, J.R. 2004. Calcareous nannoplankton evolution and diversity through time. In Thierstein, H.R. \& Young, J.R. (Eds), Coccolithophores - From Molecular Processes to Global Impact. Springer-Verlag, Heidelberg, 481-505.

Caron, M. \& Homewood, P. 1983. Evolution of early planktic foraminifers. Marine Micropaleontology, 7: 453-462.

Chumakov, N.M. \& Frakes, L.A. 1997. Mode of origin of dispersed clasts in Jurassic shales: southern part of the Yana-Kolyma fold belt, NE Asia. Palaeogeography, Palaeoclimatology, Palaeoecology, 128: 77-85.

De Vargas, C., Aubry, M.-P., Probert, I. \& Young, J. 2007. Origin and evolution of coccolithophores: From coastal hunters to oceanic farmers. In Falkowski, P.G. \& Knoll, A.H. (Eds), Evolution of Primary Producers in the Sea. Elsevier Academic Press, London, 251-285.

Dromart, G., Garcia, J.P., Picard, S., Atrops, F., Lècuyer, C. \& Sheppard, S.M.F. 2003. Ice age at the Middle-Late Jurassic 'Transition'. Earth \& Planetary Science Letters, 213: 205-220.

Duff, K.L. 1975. Palaeoecology of a bituminous shale - the Lower Oxford Clay of Central England. Palaeontology, 18: 443-482.

Erba, E. 2006. The first 150 million years history of calcareous nannoplankton: biosphere-geosphere interactions. Palaeogeography, Palaeoclimatology, Palaeoecology, 232: 237-250.

Etter, W. 1996. Pseudoplanktonic and benthic invertebrates in the Middle Jurassic Opalinum Clay, northern Switzerland. Palaeogeography, Palaeoclimatology, Palaeoecology, 126: 325-341.

Falkowski, P.G., Schofield, O., Katz, M.E., Van De Schootenbruggem, B. \& Knoll, A.H. 2004. Why is land green and the ocean red? In Thierstein, H.R. \& Young, J.R. (Eds), Coccolithophores: From Molecular Processes to Global Impact. Springer-Verlag, Heidelberg, 429-453.

Fortwengler, D. 1989. Les 'Terres Noires' d'âge Callovien supérieur à Oxfordien moyen des chains subalpines du sud. Comptes Rendus Académie des Sciences, Paris, 308: 531-536.

Fuchs, W. 1967. Ober Ursprung und Phylogenie der Trias-'Globigerinen' und die Bedeutung dieses Formenkreises für das echte Plankton. Verhandlungen der Geologischen Bundesanstalt, Wien 1967: 135-177.

Fuchs, W. 1970. Eine alpine, tiefliassische Foraminiferenfauna von Hernstein in Niederösterreich. Verhandlungen der Geologischen Bundesanstalt, Wien, 1970: 66-145.

Fuchs, W. 1973. Ein Beitrag zur Kenntnis der Jura-'Globigerinen' und verwandter Formen an Hand polnischen Materials des Callovien und Oxfordien. Verhandlungen der Geologischen Bundesanstalt, Wien, 1973: 445-487.
Garisson, R.E. \& Fischer, A.G. 1969. Deep-water limestones and radiolarites of the Alpine Jurassic. In Friedman, G.M. (Ed.), Depositional Environments in Carbonate Rocks. Special Publication of the Society of Economic Paleontologists and Mineralogists, Tulsa, 14: 20-56.

Gedl, P., Kaim, A., Boczarowski, A. et al. 2003. A reconstruction of sedimentary environment of Middle Jurassic ore-bearing clay from Gnaszyn (Częstochowa region) - preliminary results. Tomy Jurajskie, 1: 19-27.

Golonka, J. \& Krobicki, M. 2001. Upwelling regime in the Carpathian Tethys: a Jurassic-Cretaceous palaeogeographic and paleoclimate perspective. Geological Quarterly, 45: 15-32.

Görög, A. \& Wernli, R. 2003. Palaeobiogeography of the middle Jurassic protoglobigerinids. Eclogae Geologica Helvetiae, 96: 237-248.

Grigelis, A.A. 1958. Globigerina oxfordiana sp. n. - an occurrence of Globigerina in the Upper Jurassic strata of Lithuania [in Russian]. Nauchnye Doklady Vysshei Shkoly, Geologo-Geograficheskie Nauki, 1958(3): 109-111.

Grigelis, A.A. 1985. Zonalnaya Stratigrafiya, v Baltsikoi Yuri po Foraminiferam. Ypravlenie Geologii Litovskoi SSR, Litovskii Nauchno-Issledovatelskii Geologorazvedochnii Institut, Moskva, 'Nedra', 130pp.

Grigelis, A.A. \& Gorbachik, T.N. 1980. Morphology and taxonomy of Jurassic and Early Cretaceous representatives of the Superfamily Globigerinacea (Favusellidae). Journal of Foraminiferal Research, 13: 180-190.

Grigelis, A.A., Mesezhinikov, M.S. \& Yakovleva, S.P. 1977. The first finds of planktonic foraminifera in the Upper Jurassic of the Pechora River basin. Doklady Akademii Nauk SSSR, 233: 926-927. [in Russian]

Haeusler, R. 1881. Untersuchungen über die microscopischen Structurverhältnisse der Aargauer Jurakalke mit besonderer Berüksichtigung ihrer Foraminiferenfauna. PhD Thesis, University of Zürich, Brugg: 1-47.

Hancock, J.M. 1976 [for 1975]. The petrology of the Chalk. Proceedings of the Geologists' Association, 86: 499-535.

Hart, M.B. 1980. A water depth model for the evolution of the planktonic Foraminiferida. Nature, 286: 252-254.

Hart, M.B. 1999. The evolution and biodiversity of Cretaceous planktonic Foraminiferida. Géobios, 32: 247-255.

Hart, M.B. 2008. Cretaceous foraminifera from the Turonian succession at Beer, southeastern Devon, England. Cretaceous Research, 29: $1035-1046$.

Hart, M.B. \& Bailey, H.W. 1979. The distribution of planktonic Foraminiferida in the mid-Cretaceous of NW Europe. Aspekte der Kreide Europas, IUGS, Series A, 6: 527-542.

Hart, M.B., Oxford, M.J. \& Hudson, W. 2002. The early evolution and palaeobiogeography of Mesozoic planktonic foraminifera. In Crame, J.A. \& Owen, A.W. (Eds), Palaeobiogeography and Biodiversity Change: the Ordovician and Mesozoic-Cenozoic Radiations. Geological Society, London, Special Publications, 194: 115-125.

Hart, M.B., Hylton, M.D., Oxford, M.J., Price, G.D., Hudson, W. \& Smart, C.W. 2003. The search for the origin of the planktonic foraminifera. Journal of the Geological Society, London, 160: 341-343.

Hart, M.B., Aze, T., Hudson, W. \& Smart, C.W. 2007. Planktic foraminifera from the proposed GSSP for the Oxfordian Stage: Redcliff Point, near Weymouth. Geoscience in south-west England, 11: 273-279.

Hesselbo, S.P. \& Coe, A.L. 2000. Jurassic sequenes of the Hebrides Basin, Isle of Skye, Scotland. In Graham, J.R. \& Ryan, A. (Eds), Field Trip Guidebook, International Association of Sedimentologists, Meeting, Dublin, 41-58.

Hu, X., Jansa, L., Wang, C. et al. 2005. Upper Cretaceous oceanic red beds (CORBs) in the Tethys: occurrences, lithofacies, age, and environments. Cretaceous Research, 26: 3-20.

Huddleston, R.W. 1982. Comments on the nomenclatural status of the families Caucaselldae and Favusellidae (Foraminiferida). Proceedings of the Biological Society of Washington, 95: 637-638. 
Hudson, W., Hart, M.B., Sidorczuk, M. \& Wierzbowski, A. 2005. Jurassic foraminifera from Pieniny Klippen Belt and their taxonomic and phylogenetic importance (Carpathians, southern Poland). Tomy Jurajskie, 3: 1-10.

Hudson, W., Hart, M.B. \& Smart, C.W. 2009. Palaeobiogeography of early planktic foraminifera. Bulletin, Société géologique de France, 180: $27-38$.

Jefferies, R.P.S. \& Minton, P. 1965. The mode of life of two Jurassic species of 'Posidonia'. Palaeontology, 8: 156-185.

Jenkyns, H.C., Jones, C.E., Gröcke, D.R., Hesselbo, S.P. \& Parkinson, D.N. 2002. Chemostratigraphy of the Jurassic System: applications, limitations and implications for palaeoceanography. Journal of the Geological Society, London, 159: 351-378.

Katz, M.E., Finkel, Z.V., Grzebyk, D., Knoll, A.H. \& Falkowski, P.G. 2004. Evolutionary trajectories and biogeochemical impacts of marine eukaryotic phytoplankton. Annual Reviews of Ecological and Evolutionary Systems, 35: 523-556.

Katz, M.E., Fennel, K. \& Falkowski, P.G. 2007. Geochemical and biological consequences of phytoplankton evolution. In Falkowski, P.G. \& Knoll, A.H. (Eds), Evolution of Primary Producers in the Sea. Elsevier Academic Press, London, 405-430.

Kennett, J. 1982. Marine Geology. Prentice Hall Inc., New Jersey.

Kołodziej, B., Jurkowska, A., Banaś, M. \& Ivanova, D. 2011. Improving detection of foraminifera by cathodoluminescence. Facies, 57: 571-578.

Krobicki, M. \& Wierzbowski, A. 2004. Stratigraphic position of the Bajocian crinoidal limestones and their palaeogeographic significance in evolution of the Pieniny Klippen Basin. Tomy Jurajskie, 2: 69-82.

Kusnetzova, K.I. \& Uspenskaya, E.A. 1980. Novie nakhdki planktonnikh foraminifer $\mathrm{v}$ verkhneyurskikh otlozhenii Krima. Doklady Akademii Nauk SSSR, 259: 748-751.

Leckie, R.M. 1985. A paleoceanographic model for the early evolutionary history of planktonic forminifera. Palaeogeography, Palaeoclimatology, Palaeoecology, 73: 107-138.

Leckie, R.M. 1987. Paleoecology of mid-Cretaceous planktonic foraminifera: A comparison of open ocean and epicontinental sea assemblages. Micropaleontology, 33: 164-176.

Lewandowski, M., Krobicki, M., Matyja, B.A. \& Wierzbowski, A. 2005. Palaeogeographic evolution of the Pieniny Klippen Basin using stratigraphic and palaeomagnetic data from the Veliky Kamenets section (Carpathians, Ukraine). Palaeogeography, Palaeoclimatology, Palaeoecology, 216: 53-72.

Martin, R.E. 1995. Cyclic and secular variation in microfossil biomineralization: clues to the biogeochemical evolution of Phanerozoic Oceans. Global and Planetary Change, 11: 1-23.

Martin-Garin, B., Lathuilière, B., Geister, J. \& Ramseyer, K. 2010. Oxygen isotopes and climatic control of Oxfordian Coral reefs (Jurassic, Tethys). Palaios, 25: 721-729, DOI: 10.2110/palo.2010. p10-027r.

Matyja, B.A. \& Głowniak, E. 2003. Lower and Middle Oxfordian ammonite succession of the Ogrodzieniec quarry section, and its biogeographic importance [in Polish]. Tomy Jurajskie, 1: 53-58.

Messenger, R.W., Hart, M.B., Smart, C.W., Leng, M.J., Lock, E.J. \& Howard, A.K. 2010. Pteropod faunas as indicators of late Pleistocene climate change in the Caribbean Sea. In Whittaker, J.E. \& Hart, M.B. (Eds), Micropalaeontology, Sedimentary Environments and Stratigraphy: A Tribute to Dennis Curry (1912-2001). The Micropalaeontological Society, Special Publications, 17-28, DOI: 10.1144/TMS004.3.

Mišík, M. \& Soták, J. 1998. 'Microforaminifers' - a specific fauna of organic-walled foraminifera from the Callovian-Oxfordian limestones of the Pieniny Klippen Belt. Geologica Carpathica, 49(2): 109-123.

Morozowa, V.G. \& Moskalenko, T.A. 1961. Planktonnie foraminiferi progranichnikh otlozhenii Bayosskogo i Batskogo yarusov tsentral'nogo Dagestana (severo-vostochnii Kavkaz). Voprosy Mikropaleontologii, 5: $3-30$.
Murray, J. \& Renard, A.F. 1891. Deep-sea Deposits. Report of the Scientific Results of the voyage of H.M.S. Challenger, 1873-1876, Eyre \& Spotiswode, London, 525pp.

Oberhauser, R. 1960. Foraminiferen und Mikrofossilien 'incertae sedis' der Ladinischen und karnischen Stufe der Trias aus den Ostalpen und aus Persien. In Oberhauser, R., Kristan-Tollmann, E., Kollman, K. \& Klaus, W. (Eds), Beiträge zur Mikropaläontologie der Alpinen Trias, Jahrbuch der Geologischen Bundesanstalt, Wien, 5: 5-46.

Olszewska, B. 1983. A contribution to the knowledge of planktonic foraminifers of the Globigerina Submenilite Marls in the Polish Outer Carpathians. Kwartalnik Geologiczny, 27: 547-570.

Olszewska, B. 1984. Benthic foraminifera of the Submenilite Globerigerina Marls of Polish Outer Carpathians. Prace Instytutu Geologicznego, 110: $1-37$.

Oschmann, W. 1994. Adaptive pathways of benthic organisms in marine oxygen-controlled environments. Neues Jahrbuch für Geologie und Paläontologie, Abhandlungen, 191: 393-444.

Pazdrowa, O. 1969. Bathonian Globigerina of Poland. Rocznik Polskiego Towarzystwa Geologicznego, 39(1-3): 41-56.

Pearce, C.R., Hesselbo, S.P. \& Coe, A.L. 2005. The mid-Oxfordian (Late Jurassic) positive carbon-isotope excursion recognised from fossil wood in the British Isles. Palaeogeography, Palaeoclimatology, Palaeoecology, 221: 343-357.

Pelseneer, P. 1888. Report on the Pteropoda. Report on the Scientific Results of the voyage of H.M.S. Challenger, 1873-1876, Zoology, part 65. HMSO, London, 23: 1-97.

Petrizzo, M.R. \& Huber, B.T. 2006. Biostratigraphy and taxonomy of late Albian planktonic foraminifera from ODP Leg 171B (Western North Atlantic Ocean). Journal of Foraminiferal Research, 36: 166-190.

Philippe, M. \& Thevenard, F. 1996. Distribution and palaeoecology of the Mesozoic wood genus Xenoxylon: palaeoclimatological implications for the Jurassic of Europe. Review of Palaeobotany and Palynolgy, 91: 353-370.

Podlaha, O.G., Mutterlose, J. \& Veizer, J. 1998. Preservation of $\delta^{18} \mathrm{O}$ and $\delta^{13} \mathrm{C}$ in belemnite rostra from the Jurassic/early Cretaceous successions. American Journal of Science, 298: 324-347.

Price, G.D. 1999. The evidence and implications of polar ice during the Mesozoic. Earth Science Reviews, 48: 183-210.

Ridgwell, A. 2005. A mid-Mesozoic revolution in the regulation of ocean chemistry. Marine Geology, 217: 339-357.

Ridgwell, A. \& Zeebe, R.E. 2005. The role of the global carbonate cycle in the regulation and evolution of the Earth system. Earth and Planetary Science Letters, 234: 299-315.

Riegraf, W. 1987. Planktonic foraminifera (Globuligerinidae) from the Callovian (Middle Jurassic) of southern Germany. Journal of Foraminiferal Research, 17: 190-211.

Royer, D.L. 2006. $\mathrm{CO}_{2}$-forced climate thresholds during the Phanerozoic. Geochimica et Cosmochimica Acta, 70: 5665-5675.

Sidorczuk, M. 2005. Middle Jurassic ammonitico rosso deposits in the northwestern part of the Pieniny Klippen Belt in Poland and their palaeogeographic importance; A case study from Stankowa skała and 'Wapiennik' Quarry in Szaflary. Annales Societatis Geologorum Poloniae, 75: 273-285.

Sidorczuk, M. \& Nejbert, K. 2008. Genesis of ferromanganese crusts in Jurassic pelagic limestones at Stankowa Skała, Pieniny Klippen Belt, Poland: sedimentological and petrological approach. Volumina Jurassica, 6: 75-85.

Simmons, M.D., BouDagher-Fadel, M.K., Banner, F.T. \& Whittaker, J.E. 1997. The Jurassic Favusellacea, the earliest Globigerinina. In BouDagher-Fadel, M.K., Banner, F.T. \& Whittaker, J.E. (Eds), The Early Evolutionary History of Planktonic Foraminifera. Chapman \& Hall, London, 17-51.

Smoleń, J. in press. Faunal dynamics of foraminifer assemblages in the Bathonian (Middle Jurassic) ore-bearing clays at Gnaszyn, KrakówSilesia Homocline, Poland. Acta Geologica Polonica. 
Stam, B. 1986. Quantitative analysis of middle and late Jurassic foraminifera from Portugal and its implications for the Grand banks of Newfoundland. Utrecht Micropaleontological Bulletins, 34: 1-168.

Stanley, S.M. 2006. Influence of seawater chemistry on biomineralization throughout phanerozoic time: Palaeontological and experimental evidence. Palaeogeography, Palaeoecology, Palaeoecology, 232: 214-236.

Stanley, S.M. \& Hardie, L.A. 1998. Secular oscillations in the carbonate mineralogy of reef-building and sediment-producing organisms driven by tectonically forced shifts in seawater chemistry. Palaeogeography, Palaeoclimatology, Palaeoecology, 144: 3-19.

Steiner, C., Hobson, A., Favre, P., Stampfli, G.M. \& Hernandez, J. 1998. Mesozoic sequence of Fuerteventura (Canary Islands): Witness of Early Jurassic sea-floor spreading in the Central Atlantic. Geological Society of America, Bulletin, 110: 1304-1317.

Tremolada, F., Erba, E., Van de Schootbrugge, B. \& Mattioli, E. 2006. Calcareous nannofossil changes during the late Callovian-early Oxfordian cooling phase. Marine Micropaleontology, 59: 197-209.

Tyszka, J. 1994. Palaeoenvironmental implications from ichnological and microfaunal analysis of Bajocian spotty carbonates, Pieniny Klippen Belt, Polish Carpathians. Palaios, 9: 175-187.

Tyszka, J. 1999. Foraminiferal biozonation of the Early and Middle Jurassic in the Pieniny Klippen Belt (Carpathians). Bulletin of the Polish Academy of Sciences, Earth Sciences, 47(1): 27-46.

Wall-Palmer, D., Hart, M.B., Smart, C.W. et al. 2011. Pteropods from the Caribbean Sea: dissolution as an indicator of past ocean acidification. Biogeosciences Discussions, 8: 6901-6917.

Wernli, R. 1988. Les protoglobigérines (foraminifères) du Toarcien et de l'Aalenien du Domuz Dag (Taurus Occidental, Turquie). Eclogae Geologicae Helvetiae, 81: 661-668.

Wernli, R. 1995. Les foraminifères globigériniformes (Oberhauserellidae) du Toacien inférieu de Teysachaux (Préalpes medians, Fribourg, Suisse). Revue de Paléobiologie, 14: 257-269.
Wernli, R. \& Görög, A. 1999. Protoglobigerinids (Foraminifera) acid extracted from Bajocian limestones (Hungary). Revista Española Micropaleontologia, 31(3): 123-130.

Wernli, R. \& Görög, A. 2000. Determination of Bajocian protoglobigerinids (Foraminifera) in thin sections. Revue de Paléobiologie, 19(2): 399-407.

Wierzbowski, H. \& Joachimski, M. 2007. Reconstruction of late Bajocian-Bathonian marine palaeoenvironments using carbon and oxygen isotope ratios of calcareous fossils from the Polish Jura Chain (central Poland). Palaeogeography, Palaeoclimatology, Palaeoecology, 254(3-4): 523-540.

Wierzbowski, H. \& Rogov, M. 2011. Reconstructing the palaeoenvironment of the Middle Russian Sea during the Middle-Late Jurassic transition using stable isotope ratios of cephalopod shells and variations in faunal assemblages. Palaeogeography, Palaeoclimatology, Palaeoecology, 299: 250-264.

Wierzbowski, A., Jaworska, M. \& Krobicki, M. 1999. Jurassic (Upper Bajocian-lowest Oxfordian) ammonitico-rosso facies in the Pieniny Klippen Belt, Carpathians, Poland: its fauna, age, microfacies and sedimentary environment. Studia Geologica Polonica, 115: 7-74.

Wierzbowski, A., Aubrecht, R., Golonka, J. et al. (Eds). 2006. Jurassic of Poland and adjacent Slovakian Carpathians. Field Trip Guidebook of the 7 th International Congress on the Jurassic System, Kraków, September 6-18, 2006. University of Warsaw, Poland, 235pp.

Wierzbowski, H., Dembicz, K. \& Praszkier, T. 2009. Oxygen and carbon isotope composition of Callovian-Lower Oxfordian (MiddleUpper Jurassic) belemnite rostra from central Poland: A record of a Late Callovian global sea-level rise? Palaeogeography, Palaeoclimatology, Palaeoecology, 283: 182-194.

Young, J.R., Geisen, M. \& Probert, I. 2005. Review of selected aspects of coccolithophore biology with implications for paleobiodiversity estimation. Micropaleontology, 51: 267-288. 


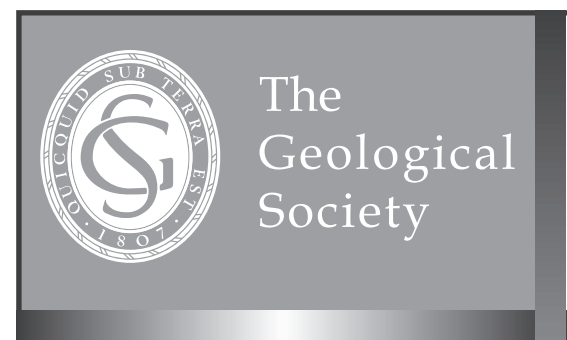

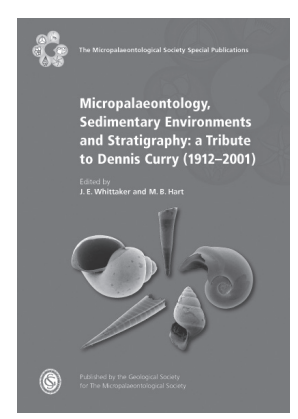

-ISBN: 978-1-86239-305-9

- September 2010

-304 pages

-Prices:

List: $£ 90.00 / U S \$ 180.00$

GSL: $f 54.00 / U S \$ 108.00$

TMS: $\mathbf{4} 45.00 / U S \$ 90.00$

Online bookshop code:

TMSO04
- The Micropalaeontological Society Series (TMS)

\section{Micropalaeontology, Sedimentary Environments and Stratigraphy: A Tribute to Dennis Curry (1912-2001)}

\author{
Editors: J. E. Whittaker \& M. B. Hart
}

Dennis Curry was a remarkable polymath and philanthropist, leading a double-life as one of the UK's most gifted amateur geologists, whilst at the same time being an extremely successful businessman (as Managing Director of Currys Ltd). This Festschrift, authored by friends and specialists from Britain and France, pays tribute to his often seminal research as well as exhibiting the wide range of his geological interest. It contains 12 chapters and covers several differing aspects of micropalaeontology (pteropods, diatoms and especially foraminifera), Strontium Isotope Stratigraphy, Hampshire Basin stratigraphy and palaeogeography, as well as major contributions on English Channel sedimentology and the great faunal turnover affecting mammals at the Eocene-Oligocene boundary. A scientific appreciation of Dennis Curry, 'the professional amateur', with recollections of former colleagues at University College, London (where he was Visiting Professor), together with an assessment of the valuable collections he established and donated to The Natural History Museum, are also included. Copiously illustrated, this book is a must for all geologists.

Postage: UK: $+5 \%$ ( $£ 4.50$ minimum) Europe: $+15 \%$ ( $£ 9.00$ minimum) Rest of world: $+15 \%$ ( $€ 13.50$ minimum) All prices and postage valid until 31 December 2011. Please allow up to 28 days for delivery of in stock items in the UK. Parcels to Europe and Rest of World are sent by surface mail and can take 6 to 12 weeks to arrive. (Air or courier rates available on request).

Please order from: Geological Society Publishing House, Unit 7 Brassmill Enterprise Centre, Brassmill Lane, Bath BA1 3JN, UK Tel: +44 (0)1225 445046 Fax: +44 (0)1225 442836 Email: sales@geolsoc.org.uk Online bookshop: www.geolsoc.org.uk/bookshop Society Web Site: www.geolsoc.org.uk

For full details see the Online Bookshop: www.geolsoc.org.uk/bookshop
The Geological Society's Lyell Collection: journals, Special Publications and books online. For more information visit www.geolsoc.org.uk/LyellCollection 